See discussions, stats, and author profiles for this publication at: https://www.researchgate.net/publication/346327451

\title{
Multinational corporations and human right violations in emerging economies: Do commitment to social and environmental responsibility matter?
}

Article in Journal of Environmental Management · November 2020

DOI: 10.1016/j.jenvman.2020.111689

CITATIONS

0

4 authors:

Subhan Ullah

University of Nottingham

22 PUBLICATIONS 170 CITATIONS

SEE PROFILE

Dawda Adams

University of Hull

3 PUBLICATIONS 30 CITATIONS

SEE PROFILE
READS

49

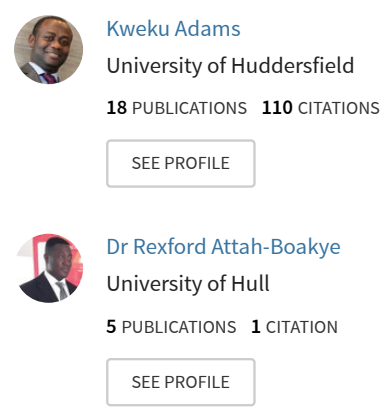

Some of the authors of this publication are also working on these related projects:

Risk Perceptions and Risk Management Approaches of Chinese Overseas Investors: An Empirical Investigation, View project

Call for Book Chapters View project 


\title{
Please cite this paper as:
}

Ullah, S., Adams, K., Adams, D., Attah-Boakye, A. (2020) Multinational corporations and human rights violations in emerging economies: do commitment to social and environmental responsibility matter? Journal of Environmental Management, Forthcoming.

\section{Multinational corporations and human rights violations in emerging economies: do commitment to social and environmental responsibility matter?}

\begin{abstract}
The surge in economic growth in the global-north vis-a-vis social and economic inequalities in the global-south (north-south dichotomy) has led to critical research and policy implications for human rights considerations in emerging economies. This paper draws on the concept of convergence and institutional theories to enhance our understanding of how multinational corporation's (MNCs) fulfil their profit maximisation agenda using capitalist principles; and the extent to which these ideologies produces human rights violations in emerging economies. Using multiple data sources from the Human Rights Watch, our study provides a comprehensive list of various human rights violations perpetrated by MNCs from 2002 - 2017. We uncovered 273 violations by 160 MNCs mostly from developed countries. More than $90 \%$ of our sample firms have CSR/sustainability committees, are signatories to the UN Global Compact and have reported compliance with International Labour Organization (ILO). This raises questions about the effectiveness of these programmes. We contribute to the $\mathrm{CSR} /$ sustainability literature by providing new insights into the nature and location of human rights abuses committed by MNCs.
\end{abstract}

Keywords: Multinational corporations, human rights violations, poverty and inequalities, emerging economies.

\section{Acknowledgment:}

Dawda Adams was an Accounting and Finance $\mathrm{PhD}$ student at the Adam Smith Business School, University of Glasgow. He started his MSc Accounting and Finance as a self-funded student at the University of Hull and graduated in 2017 with distinction. He won the Faculty of Business Law and Politics Dean's Prize for the highest grades. Within a few months of completion, he published two articles in Resources Policy which has gained numerous citations. Prior to this, he held Bachelor of Business Administration (Accounting - First Class) and Psychology with Sociology (Second Class Upper) from the University of Ghana. He also held Diploma in Labour Studies (First Class) and Certificate in Labour Studies (First Class) from the University of Cape Coast, Ghana. Until his PhD studies at Adam Smith Business School, Dawda was the Executive Director of Humanitarian Foundation, Ghana since 2010. Dawda sadly passed away on 13 July 2020 after a brief illness. We posthumously acknowledge his contribution to the conception, design and writing of this manuscript. 
May God bless Dawda's soul and the souls of academics who passed on during their quest to advance knowledge.

\subsection{Introduction}

Hoskisson et al. (2000) define emerging markets as "low-income, but rapid-growth countries using economic liberalisation as their primary engine of growth". Nine years after Hoskisson et al.'s (2000) definition of emerging economies, Prahalad (2009) confirms that most of the world's population who are at the Bottom of the Pyramid (BoP) live in these economies. In this work, the author argues for inclusive capitalism, justice, community engagement programmes, and socially responsible corporate actions. Prior to Prahalad's (2009) work, Hinings and Greenwood (2002) argued that multinational corporations (MNCs) must strategise beyond increasing shareholder returns by taking an active role in society because of the wide-ranging and deep-seated environmental and socio-economic problems caused by globalisation. To sustainably satisfy shareholders objective, MNCs take advantage of the confluence of global capitalism and resource orchestration by utilising their unique capabilities to invest in economies that guarantee maximum profits. Whilst corporate profitability is not bad, MNCs' 'strategic' investment decisions in countries struggling with weaker institutions have provoked considerable academic and policy debates concerning social justice (Monshipouri et al., 2003) and human rights violations (Giuliani and Macchi, 2013; Giuliani, 2018). Dentoni et al. (2018) urged international business researchers and policymakers to find solutions to what they classified as 'wicked problems' in the $21^{\text {st }}$ century. This century has created 'challenging opportunities' simultaneously for wealth creation for the global-north and a widening gap for those at the bottom of the pyramid in the global-south (Prahalad, 2009). Global challenges such as climate change, poverty, inequality, and human rights violations seemed to have spurred the United Nations (UN) to introduce the Sustainable Development Goals (SDGs). The objective is to tackle gender inequality, ensuring peace and justice in institutionally weak emerging economies (Freer, 2017). These antecedents have encouraged various stakeholder groups and 
policymakers to hold MNCs accountable for their actions (Belal et al., 2013; Cooper et al., 2011).

Whilst business ethics scholarship has endeared MNCs to establish and maintain responsible and ethical relationships with stakeholders and intensify corporate social responsibility (CSR) in emerging economies (see Barraquier, 2011; Frynas, 2010; Amaeshi et al., 2016), recent studies point towards three emerging CSR trends in a neoliberalist fashion. Firstly, MNCs rather use CSR as a strategy to reduce investment risk and maximise profits by developing reputational capital. Secondly, MNCs use social and environmental sustainability to gain competitive advantage. Thirdly, the importance of transparency and accountability, social and environmental investment decisions are used as opportunities for legitimisation, relegating the role of justice and fairness as an optional extra in their corporate strategy toolkit. Given the evident paucity of international management research on human rights violations, this paper aims to illuminate our understanding of the harmful effect of corporate behaviour on local communities around the world by establishing the connection between business practices and human right in international business (IB).

Human rights, according to Wettstein et al. (2019) is defined as "inalienable fundamental rights to which a person is inherently entitled simply because he or she is a human being". This definition shows that the CSR narrative and/or literature is not enough to explain why MNCs' fail to adhere to social justice, morality, and environmental responsibility within weak institutional contexts (Scholte, 2007; Asmussen and Fosfuri, 2019). Thus, in response to calls for further research by Giuliani (2013); Wettstein et al. (2019); Buckley et al. (2017), this study specifically examines IB issues of child labour, human trafficking, engagement with rogue administration, infringements on rights to human life, and health and other negative impacts of MNCs' operations in emerging economies. The Paris Agreement (COP21) also requires that "Parties should, when taking action to address climate change, respect, promote, and consider 
their respective obligations on human rights, the right to health and the rights of indigenous peoples".

Consequently, the main question this paper seeks to answer is why the diffusion of sincere CSR practices and respect for human rights seems to be weak in countries that have weaker legal systems and regulatory quality? On the back of the convergence argument, it would be interesting to build a better understanding of how formal and informal institutions cause such vulnerabilities (Ullah et al., 2018). In doing so, we contribute to improving business-labour ethics, eliminate or reduce to the barest minimum human rights violations, create opportunities for building ethical global corporations, and the development of equitable and inclusive societies. To the best of our knowledge, this could be the pioneer study to bridge the gap between the efficiency and internalisation hypothesis to co-exist with fundamental principles of legality and morality vis-a-vis justice and fairness (see Santoro, 2015).

The rest of this paper is organised and proceeds by firstly critically examining the theories that explain the centrifugal and centripetal factors of FDI as well as factors accounting for the recurrence of human rights violations and abuses in certain emerging economies. Secondly, we explain the methodology adopted in gathering and analysing the data. Next, we present the findings and highlight the theoretical and practical implications as well as the policy directions. We conclude the paper by discussing the limitations of our study and avenues for future research.

\subsection{Literature review}

\subsection{FDI and the growing activities of MNCs in emerging economies}

As globalisation of the marketplace continuously intensifies, companies that conduct business only within their national borders may find it difficult to survive. One way, therefore, to cope 
with this is to expand operations beyond home country frontiers through foreign direct investments (FDI). According to Rugman and Collinson (2006), FDI involves whole or partial ownership of a company abroad which can be made by acquiring an existing company or by setting up a new overseas venture. The new overseas operations, however, could be set up either as a joint venture or a totally owned enterprise usually called a foreign subsidiary. Once a firm undertakes FDI, it becomes an MNC (Hill, 2007; Collinson et al., 2016). Dunning (2001); Dunning and Lundan (2008), therefore, argue that MNCs undertake FDI for the purposes of ownership, re/location, and internalisation to maximise owners' equity. This argument presupposes that the primary motivation that drives the FDI decisions of all MNCs, irrespective of their country of origin, is profit maximisation. MNCs, therefore, take advantage of the confluence of global capitalism, utilising their unique resource capabilities to invest in economies that provide the ultimate opportunities for profit.

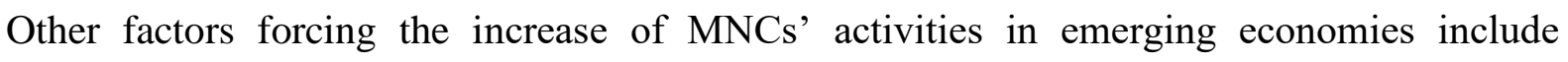
economic reform programmes (Adams et al., 2014), trade liberalisation policies (Giuliani and Macchi, 2013), openness and burgeoning democracies (Awad and Ragab, 2018), exchange rates (Shi, 2019), GDP and trade structure (Zhang and Zhang, 2018), among others. Besides, Lauwo and Otusanya (2014) suggest that the increasing flow of information technology and the rapid movement of capital around the globe have increased human rights violations in relation to the size, reach, power, and influence of MNCs. The behavioural premise upon which MNCs' strategic decisions are based has also provoked considerable academic and policy debates primarily focusing on issues of efficiency and productivity on one hand (Dunning and Lundan, 2008; Kano and Verbeke, 2019) and social justice (Monshipouri et al., 2003; Giuliani and Macchi, 2013; Giuliani, 2018) on the other.

\subsection{Convergence and glocalisation strategies of MNCs}


A stream of scholarly work focusing on the activities of MNCs in emerging economies is underpinned by the convergence theory which argues that the increasing interconnectedness of national economic systems enables firms to implement 'glocalisation' strategies (Buckley et al., 2018). Based on this perspective, MNCs see other countries as an extension of their operational territory (Kaufman, 2016; Edwards et al., 2013; Pudelko, 2005). This implies that global strategies can be implemented at the local level. MNCs are perceived as significant sources of employment, channels of technology transfer, and spill over effects (Osabutey et al., 2014) and a means by which host country governments increase local productive and consumptive capacity to maximise export revenues for socio-economic growth and development (Flanagan, 2006; Adams et al., 2014). Considering the benefits associated with FDI inflows, researchers, and policymakers tend to focus on its positive impact on society. Consequently, as policymakers normally use economic development lenses to create attractive locational incentives and tax holiday packages to attract MNCs (Blomstrom et al., 2003), they tend to disregard policies to improve social justice (Giuliani and Macchi, 2013; Braithwaite, 2006). The convergence theory and glocalisation strategies could explain the high incidences of social injustice within low-income and weak institutional economies.

\subsection{Transaction cost theory (TCE) and human rights}

The debates that explain why MNCs go abroad are rooted in the conventional theory of Ownership - Location - Internalisation (OLI) (Dunning, 2001), agency theory (Jensen and Meckling, 1976), resource-based view theory (RBV) (Peteraf, 1993) and transaction cost theory (Williamson, 1993). But Jones (1995) contends that transaction costs are critical determinants of the economic performance of MNCs and provides the clearest theoretical basis to explore human rights violations. A key aspect of the TCE theory which has been the subject of much debate is opportunism and the behavioural assumptions influencing boundedly rational managerial decision making (see Williamson, 1993; Forsgren and Holm, 2010; 
Verbeke and Greidanus, 2012). Consequently, Amaeshi et al. (2016); Dobers and Halme (2009); Frynas (2010); Sikka (2010); Wettstein et al. (2019) used the transaction cost economics perspective to confirm that that profit maximisation strategies such as tax planning, transfer pricing, low-paid workers, discrimination, violation of rights of indigenous people, child labour and forced overtime are pursued by MNCs operating in emerging economies to enhance corporate profits.

Du and Vieira (2012) and Nieri and Giuliani (2018) extend this argument by indicating that MNCs protect their hegemony by utilising supply chain accounting techniques to reduce costs in emerging economies. MNCs also use market exploitation approaches through third party contracting in order to pay lower wages. Sarpong et al. (2019) confirm that MNCs use third parties to cover bribery incidences to gain access to 'conflict minerals in conflict zones'. Other transaction cost economics studies that explain why profit maximisation agenda of MNCs lead to labour exploitation and human rights violations in emerging economies indicate that profitability is the firm's primary objective (Friedman, 2007). Barraquier (2011) find that MNCs' compliance with responsible business practices is driven by the concern for decreasing costs to increase profitability. Frynas (2010) provides several examples of how the cost-saving activities of oil and gas multinationals in Congo, Nigeria and Algeria have created wealth for shareholders in the global north but woes for the population living in the global south. Besides, MNCs use outsourcing, nearshoring, near-sourcing, and offshoring competitive posturing as strategic shields for cost minimisation (Adams et al., 2018). Feenstra and Hanson (1996); Strange and Magnani (2017) also confirm that overseas operations enable MNCs to reduce cost and maximise revenues whilst taking less responsibility for the operational consequences of their actions. Mallin (2019), therefore, presents the most relevant case study about the British Petroleum (BP) oil disaster in the Gulf of Mexico which resulted in one of the most substantial socio-economic and environmental disasters in the $21^{\text {st }}$ century. 


\subsection{Institutional context}

Relative to the convergence argument is an institutional research perspective which asserts that national origins influence the actions and strategic behaviours of MNCs (Meyer et al., 2011; Marano and Kostova, 2017). North (1991) see institutions as social interactive mechanisms that 'structure political, economic, and social interaction'. Institutions determine transaction and production costs including the feasibility and profitability of economic engagement. Business practices in emerging economies are generally characterised by chronically weak legal systems and regulatory structures (Amaeshi et al., 2008). But the extent to which the subsidiaries of MNCs adapt depends on the national institutional architecture. Based on this theoretical lens, weaker state institutions become conspicuous when an MNC violates the rights of indigenous citizens. Edwards and Ferner (2002) argue that the strength of labour market institutions in host countries usually constrains MNCs from paying lower wages. The other argument is that government influence and the host country's institutional systems have a continuing influence on MNCs approaches in the management of workforce at the local level. This reinforces what subsidiary managers of MNCs see as an acceptable norm for labour relations at the national level and employee management at the firm level (Brewster et al., 2008; Adams et al., 2017). North (1991) and Jones (1995) agree that quality institutions have the potential to induce superior productivity for profit maximisation. Dobers and Halme (2009) for instance confirms that the fair-trade movement has stalled, and its impact has waned due to institutional weaknesses in emerging economies. Ackah-Baidoo (2012) also finds that weak institutions in emerging economies have resulted in poor systems of governance which generally exerts minimal pressure on MNCs to embrace responsible management practices. Abba et al., (2018) claim that MNCs see countries with weaker institutions as exploitable. Investigating the relationship between CSR and governance within the South African economy, Ntim and Soobaroyen (2013) confirm that local institutions determine commercial activities 
and social engagement significantly. Country-level institutional factors affect how MNCs perceive their human rights commitments (Kaufmann et al., 2018). Consequently, we posit that while rules, regulations, and frameworks are necessary to conduct business activities internationally, countries with weak legal, regulatory, and judicial systems, ultimately influence the rubric MNCs follow in making strategic decisions.

\subsubsection{Isomorphic pressures on MNCs}

Whilst DiMaggio and Powell (1983) discusses the isomorphic pressures MNCs from developed countries face in localising operations, Matthews (2006); Ramachandran and Pant (2010); Marano et al. (2017) also explain why MNCs from emerging markets adopt CSR practices to overcome their liability of origin. Although 'national origin influences the actions and behaviours of MNCs', there is constantly the 'possibility for them to draw on specific systems and practices in the countries where they operate' (see Edwards and Ferner, 2002; Adams et al., 2017). This may also help to explain why human rights violations of similar proportions do not occur in advanced countries - where most MNCs originate. This also ties in with another group of scholars who believe that MNCs are culturally sensitive organisations (Hofstede, 1984; Trompenaars, 1998; Fatehi and Choi, 2019). This stream of thinking believes that though strong cultural norms put pressure on MNCs to adapt, a closer examination of their glocalisation strategies could differ from one host country to the other.

Placing alongside (a) MNCs profit maximisation agenda with (b) the institutional theory and (c) the Uppsala Model (Johanson and Vahlne, 1977) leads us to question how firms develop their level of knowledge and experiences operating in different markets. Do firms learn within weak institutional contexts not to comply with local regulations? Or do they abandon their existing CSR initiatives because of weaker systems of accountability? More crucially, the pathway they choose to grow their 'understanding and experience' of the host country's social 
and political institutions should naturally enable them to finetune their existing strategies to reduce local cost of production (including human rights infringements). While it might be too simplistic to assume that the profit maximisation agenda of MNCs lead to unethical business practices and human rights violations, it appears that such practices occur within weak institutional structures (see Ntim and Soobaroyen, 2013; Amaeshie et al., 2016).

On the back of these issues, therefore, this research posits the following key research questions: (i) how and to what extent do MNC's convergence and glocalisation ideology drive human rights violations? and (ii) to what extent does institutional weaknesses contribute to human rights violations in emerging economies? In an attempt to answer these questions, it seems expedient to reconsider the concept of CSR to re-establish the importance of human rights and what constitutes a violation to be able to draw a clear point of intersection where international business scholarship and international law governing such rights meet.

\subsection{Neo-liberal CSR and human rights in international business}

In the International Business (IB) field, several academic outlets have explored issues relating to responsible business practices based on morality and society, popularly referred to as CSR. A great number of studies on CSR and government policies have subsequently been shaped on this rhetoric. Recently, however, Tung and Stahl (2018) have shifted the discussion from the conventional demands of CSR, calling for accountable and transparent MNCs. Yet, none of the studies on CSR nor cross-cultural management literature seems to offer a tangible explanation of the rising human rights violations by MNCs widely reported in several media and academic outlets (See Duke, 2020; Cohen, 2020; Worster, 2020). The UN Universal Declaration of Human Rights (1948) defines human rights as 'the political, civil, socio-economic and cultural rights'. The social constructivists see human rights as the fundamental need for human existence. This is what Maslow (1943) contextualises in the realm of human motivation which has been used in strategic management circles for decades. In his work, O’Manique (1992) 
presents three major propositions upon which human satisfaction consist: ought to survive, necessary for survival and ought to have. It is eminent that the real hurdle lies in the attainment of the first. Moreover, the deontological ethical scholars assert that a moral action must be based on a set of rules rather than the consequences of the action. Paying workers well and treating employees fairly is an undeniable right of any human being, even in countries where the institutional framework is weak. Yet as political and social rights are supposed to be provided and protected by the state, emerging economies, desperate to attract FDI to improve exports and reduce unemployment finds it difficult to protect citizens by enforcing these rights. Richards et al. (2001) discover a low level of government respect for human rights in developing countries if foreign capital inflows lead to positive economic outcomes. In other words, governments would accept the liberal economic doctrine, if the consistency of overseas financial inflows outweighs the perceived political and human rights consequences (De Soysa and Vadlamannati, 2011).

Studies on human rights violations seem to emerge from human rights law whereas CSR and principles for responsible practices descend from management scholarship. Given the noxious impact of FDI on host developing countries, Stiglitz (2006) has questioned the merits of the biopolitics of circulation, globalisation, and impact of capitalism. Whilst Stiglitz (2006) and Rodrik (2017) raise concerns about the negative effects of MNCs' activities in the global south, where private incentives are not aligned with social and moral costs, it has become necessary to merge these two fields - human rights violations and CSR. Giuliani (2018) contends that MNCs may be causing more social inequality than what is being perceived. On the back of these issues, it is reasonable to indicate that the IB scholarship has been unfair in acknowledging the pitfalls of global capitalism and capital flows as it has been more focused on understanding its virtues and rationales using a set of IB-centred, strategic managementinformed theories (Giuliani, 2018; Adams et al., 2018). Whilst it is largely unclear in the IB 
scholarship whether MNCs are governed by boundedly rational decision-makers who sometimes operate under conditions of uncertainty and weak institutional contexts, or whether they help to perpetuate human rights violations unknowingly, shows the importance of this study.

\section{Methodology and data sources}

\subsection{Data sources}

We use multiple data sources from the Human Rights Watch which provide a comprehensive list of human right violations by MNCs. We explore a list of MNCs engaging in human rights scandals from the Human Rights Watch website. In Table 1, we report a total of 273 human rights violations in emerging economies perpetrated by 160 different MNCs originating from 24 different countries.

\section{Insert Table 1 about here}

Using a list of MNCs engaging in human rights violations we then searched for detailed media stories relating to each violation in different media outlets. Applying a content analysis approach on the media stories, we further categorise the nature of these violations, identify the country-of-origin of MNCs having negative media coverage relating to human rights violations, and, subsequently, the penalty/sanctions imposed in response to these scandals. The content analysis approach is widely used in understanding issues relating to corporate disclosure. This method is used in analysing annual reports, CEO letters, media stories, corporate governance reports, corporate social responsibility reports, and sustainability reports (Unerman, 2000; Beck et al., 2010). We further separate human rights issues into different categories. We finally use the Bloomberg database to collect data on these firms' commitments 
to human rights principles and business ethics. In particular, we search for data relating to these MNCs on Bloomberg, if they have: (a) CSR/sustainability committee; (b) signatory to UN Global Compact; (c) member of the Ethical Trading Initiative; (d) has a human rights policy; (e) reports ILO (International Labour Organisation) compliance; (f) discloses explicit commitment to business ethics; and (g) publishes a policy on whistle-blower protection.

With the emergence of increasing stakeholders' emphasis on the quality of corporate disclosure (financial, governance, CSR, and sustainability disclosure), researchers have used a variety of theoretical lenses to uncover the meaning and interpretations in corporate communication documents (disclosure). Content analysis is an attempt to understand variations in the quantity and quality of information reported in corporate documents. Though qualitative (thematic) and quantitative (mechanistic) content analysis can be applied by researchers in contrasting methodological paradigms (interpretivism in the former case and positivist in the latter scenario) (Beck et al., 2010). Mechanistic content analysis entails some advantages and can be tested for a much larger sample with a greater degree of generalisability. On the other hand, thematic content analysis involves detailed scrutiny of underlying text in investigation, therefore, it is technically not possible to carry out such analysis for a large sample of annual reports. We are also aware that the coding of texts may involve subjective interpretations. However, we did validate our results by applying an independent coding scheme for the pilot sample of five media stories relating to human rights violations. This validation process involved two independent coders. Content analysis has been extensively applied in prior research to understand corporate legitimacy tactics (Vourvachis et al., 2016), impression management (Merkl-Davies and Brennan, 2011), and the hide-and-seek in corporate communications after corporate scandals (Rudkin et al., 2018). In the following section, we provide a detailed overview of our findings and we discuss the results. The analysis combines both frequency tables as well as actual cases/incidences to trace where and why such violations 
occur. Following the work of Yin (2003) and Eisenhardt (2007), we realise the importance of using actual case studies and frequencies to trace human rights violations and this has yielded some interesting results.

\section{Findings and discussions}

The findings from this study contribute to the extant CSR and weak institutional treatise in developing countries by extending our understanding concerning the negative relationship between CSR disclosure and corporate actions (Tashman et al., 2019) within weak institutional contexts (North, 1991; Kostova, 1997; Ntim and Soobaroyen, 2013). Further, this study seeks to deepen our knowledge and understanding of how CSR avoidance has progressed to corporate hypocrisy (Jauernig and Valentinov, 2019). Wagner et al. (2009) indicate corporate hypocrisy as 'appearing moral without paying the cost'. They argue that most empirical studies about MNC's CSR commitment in developing countries have been held hostage due to their adverse effects on corporate reputations. They cite 'credible hostages' to including incidences of human rights violations perpetrated by MNC's. This study, therefore, provides new insights into human rights violations by most MNCs operating in emerging economies.

Results from table 1 show that firstly, most MNCs are listed in developed economies, yet the greatest number of human rights violations occurred in developing or emerging economies. Secondly, MNCs originating from the most advanced countries have the highest human right violations. For instance, the UK has $20 \mathrm{MNCs}$ with 61 human rights violations while the USA with 68 MNCs recorded 88 incidences of violations. That makes MNCs from the UK and US the leading human rights violators according to the data.

Two main reasons account for the higher human rights violation by US and UK firms in our sample. First, previous studies such as Kahn-Nisser (2019) and Barry et al., (2013) show that 
UK and US are open democratic societies as a result, MNC's from US and UK bring with them the glare of high scrutiny from international media and NGO activist groups from the investing country and the home country. The high level of scrutiny by these international human rights activists might account for the relatively higher number of Human rights abuse records for, especially US MNC's. US and UK have usually positioned themselves at the forefront of issues related to democracy and human rights violation around the world. As a result, US firms (both domestic and international) are often targeted by human rights activist all over the world. For example, the US firm Nike and Reebok are the most popular athlete footwear company in the world. These firms were targeted by human rights activist for human rights violations committed abroad not by their managers or in their plants but by the subcontractors who produced their products in overseas facilities. Also, previous studies show that most of these human rights violations by foreign MNC's are reported by international human rights NGO's (Kahn-Nisser; 2019; Barry et al., 2013) Previous studies show that the two countries that usually receive the highest number of naming and shaming are US and UK due to their strong advocates for global democracy (Kahn-Nisser; 2019; Barry et al., 2013). For example, empirical studies such as Kahn-Nisser (2019) argue that US firms are more likely to suffer naming and shamming by international human rights NGO's due to their significant voting rights at the UN general assembly on issues related to the convention against torturing (CAT) (Kahn-Nisser 2019). Last but not the least, comparatively our sample size contains a higher proportion of UK and US firms (Please refer to table 1).

\section{Insert table 1 about here}

Remarkably, those that occurred in developed countries are concentrated in the deprived regions (Adeola, 2005; Short, 2005) and racially segregated communities (Adeola 2005). Mostly, the victims of these human rights violations in all cases (including developing, 
emerging, transition and developed countries) are the poor and the vulnerable (Muchlinski, 2001; Ruggie 2007). For example, our results show 88 human rights violations in the USA involving 68 companies. Our investigations show the victims of these human rights abuses are the poor, women, children, and the most vulnerable individuals in the society as shown in table 3. In this regard, Ruggie (2007) argues that the giant US supermarket (Walmart) alone has over sixty thousand suppliers in the USA alone. Thus, the larger the supply chain the higher the number of human rights violation incidence (Ruggie 2007). The basic human rights as defined by Wettsein (2018) is the freedom to which all humans are entitled to in a democratic society (O’Manique, 1992). However, the prerogatives of inordinate global capitalist ideologies that drive MNC's operations have moved human rights to the peripheries. The ontological constructions by the MNC's operations have led to the exclusions of colonized peoples, indigenous population, the poor, women, children, the impoverished, the vulnerable etc. being ‘drawers of water and hewers of wood” (see Muchlinski 2001, Ruggie 2007).

More importantly, the convergence argument which explains the profit maximisation mindset of these MNCs coupled with weak institutional framework existing in Africa, Asia, Latin America provides significant avenues of exploitation by these MNCs. In this regard, most countries listed in table 1 are saddled with weak institutions such as poor social structures, poor legal systems, poor environmental laws, and poor corporate governance mechanisms, to mention a few. Accordingly, Muchlinski (2001) confirms that the informal institutions of most host countries of FDI provides a thriving ground for human rights violations by MNCs. In some instances, the host government and their political cronies from these developing countries may not award operating licences to ethically driven MNCs due to the prevailing state of corruption and weak institutional context existing in most host nations (see Hoskinson et al., 2013, Dobers and Halme, 2009, Ntim and Soobaroyen, 2013). 
Whilst MNCs from the Triad countries are seen as torchbearers of innovation and technology transfers (see Osabutey et al., 2014), our results from table 1-5 show that most of these human rights violations are perpetrated by MNCs mostly from the most industrialised countries in the world including Canada, Japan, Germany, France, UK, and the USA, etc. These countries constitute over $70 \%$ of the total human rights abuse in our dataset. Muchlinski (2001) argues that the reasons why these countries dominate in the MNCs saga can be traced back to the cold war era where stratifications of human rights were developed based on ideological preferences. These antecedents created liberal western powers who pursued their capital accumulation agenda through the exploitation of the poor and the vulnerable in societies (especially in Africa, Asia and Latin America) and human rights violations (Muchlinski, 2001; Giuliani, 2013; Giuliani, 2018). Similar to the critical issues identified and discussed in table 1, table 2 provides examples of human rights violations based on the primary stock exchange listing of MNCs and the country-of-incident.

\section{Insert table 2 about here}

Our findings from table 2 show that most of these MNCs engaged in human rights violations are mining companies which are mainly driven by resource exploitation and greed. This finding is consistent with Dunning's (2001) OLI paradigm as well as the resource, asset, and efficiency hypothesis (Dunning and Lundan, 2008). Most of these mining companies have little or no care about the effects of their operations on the poor communities and the ecosystems (see Giuliani, 2018). Their priority is cost reduction and profit maximisation. Also, our results show that the victims of these abuses are mainly the poor, women, children, and the vulnerable in the society. Such issues are also highlighted in prior work and researchers argue that most of the victims of human rights violations are the poor and the most vulnerable in society (Adeola, 2005; Short, 
2005; Ruggie, 2007). Remarkably, our study reveals that most of the human rights violations centre around intimidation, corruption, bribery, harassment, and poor working conditions.

Again, this strengthens our arguments that profit maximisation prospects, transaction cost and poor institutional framework constitute the prime causes to the human rights violations in the host countries (North, 1991; Kostova, 1997). Our study also reveals that a significant number of MNCs violate their own CSR regulations and corporate accountability responsibilities (Muchlinski, 2001; Amaeshi et al., 2016; Barraquier, 2011). Interestingly, CSR legislation, codes, and corporate accountability mechanisms of MNCs operating in Africa, Asia, and Latin America emerge from individual companies' country-of-incident (Vivoda and Kemp, 2019). For example, industry associations such as the Gold Miners Association of Zimbabwe, Chile, and South Africa seem to contribute to the development of such CSR activities. Sometimes it emanates from host countries' governments, certification bodies (like IOHRP - the International Organisation for Human Rights Protection), or non-governmental organisations, among others.

Several of country-specific codes cover a wide range of ethical social and environmental issues, including issues of health and safety, labour laws, and corporate governance. Sometimes, some of these codes and legislation are initiated or sponsored by a group of stakeholders. Recently, several codes and legislation are jointly developed through multi-stakeholder engagement comprising of the government, industry, civil society, environmental groups, etc. A significant amount of these CSR codes and legislation promotes ethical issues and encourage MNCs to behave in a particular way, irrespective of the location of operation (Jamali and Karam, 2018; Crane et al., 2019; Adams et al., 2019; Tashman et al., 2019). In support of the main argument presented in this study, Sarpong et al. (2019) also show that most human rights violations occur in countries where there are weak legal institutions. Our results confirm that most governments 
in the host countries (where human rights violations occur frequently) do not hold MNCs accountable for such violations and environmental transgressions due to bribery and corrupt practices by politicians (see Ntim and Soobaroyen 2013; Amaeshie et al., 2014; Sarpong et al., 2019).

Our findings reported in Table 3 show that whilst most of the MNCs who are caught up in these human rights scandals are not members of Ethical Trading Initiative with responsibility for improving working conditions of supply chain partners), a significant number of them are signatories to several high-ranking global sustainability institutions such as UN Global Compact and CSR/Sustainability Committee. Ironically, all these MNCs claim compliance with human rights policies and disclose explicit commitment to business ethics in their annual reports, but our data show abysmal compliance with these policies in practice.

\section{Insert table 3 about here}

Most of the MNCs captured in our data operate in environments characterised by effective impunity. Thus, there is no local, national, or international regulatory system or legal systems to which aggrieved parties (victims of human rights violations) can turn to for redress. Besides, our data discovered that whilst most MNCs report compliance with ILO policies, there were several recorded incidences of labour rights violations. Intriguingly, all MNCs in our data claim to have Whistle Blowing Protection Policies in place. However, a substantial number of incidences were not mentioned in their annual company reports. This finding confirms Giuliani's (2018) work who sought answers as to why MNCs may be causing more social inequalities than is perceived. Consequently, it is fair for this study to acknowledge that the virtues and rationale for understanding theories of the MNC should intertwine the pitfalls of global capitalism. Additionally, our results show that these MNCs disclose in their annual 
reports that they are committed to business ethics. The findings in this study are, therefore, in line with arguments of prior work which report is a negative association between MNCs activities and their CSR actions (see Muchlinski, 2001; Ruggie, 2007; Adams et al., 2019).

Unpacking these antecedents from the transaction cost perspective, MNCs are more committed to profit maximisation through cost reduction (see Williamson, 1993; Nieri and Giuliani, 2018, Amaeshi et al., 2008; Dobers and Halme, 2009, Frynas, 2010; Sikka, 2010). Therefore, the CSR avoidance arguments provide prominent support for MNC's profit maximisation agenda, and hence the human rights violations in emerging economies (Frynas, 2010; Sikka, 2010; 2011). In furtherance to this argument, Muchlinski (2001) posits that MNCs are not in the business of 'moral responsibility'. Most of the MNCs in our sample that involved in violations and reported CSR/Sustainability issues in their financial statements rather provided a conflicting picture about being socially responsible. Thus, their reports failed to highlight human rights violations. In this regard, we argue that MNCs indirectly use their corporate governance code and industry-based ethical standards and membership of reputable global institutions as a pretence to avoid CSR obligations and scrutiny at the practical level within institutional contexts. At the very least, CSR disclosure in the financial reports of these MNCs creates the false impression that these MNCs operate within and follows the highest ethical standards.

Our results support previous empirical findings such as Jauernig and Valentinov (2019) and Wagner et al. (2009) that argue that Human rights compliance and CSR reports by MNC's are inconsistent and hypocritical. Our results from figures 1 and 3 show that even though most of the MNC's report human rights compliance, several human rights violations still occur especially in developing and emerging economies. Also, our results in figure 4 and table 5 
imply that, although the US and UK are considered as "champions of democracy". We also noted from our analysis in table 5 that the mean human rights score of US is 0.599 between 1990-2017 compared to the global highest score of 5.4. The human rights score indicates the degree to which the government protect and respect human rights in a given country. The value ranges from around -3.8 to 5.4 (the higher the better). This results possibly account for the higher human rights violations by US MNCs in our sample. Our results provide further insights into the relatively bad human rights records by the US, the perceived global leader in terms of human rights compliance.

We also noted from figures 1-4 that emerging countries equally suffer high human rights violations due to weak institutional framework. For example, our results from table 4 show that MNC's in developing countries have a higher number of CSR/sustainability committees compared to MNC's in emerging countries. Our results imply that the economic prospects of emerging markets are attracting compendium of MNC's who care little about CSR and sustainability and continue to abuse human rights in these emerging countries. Also, we noted from figure 2 , table 4 that whistleblower protection is relatively better in developing countries in comparison to emerging countries. Table 4 shows that among the six human rights legislations, whistleblower protection constitutes the most popular in both developing and emerging countries. Our findings in figures 1-3 and tables 1 highlight that, human rights violation also occur in developed albeit G7 country. For example, the human rights abuse incidence involving BP and Exxon Mobil (Mallin, 2019) show that even the vulnerable 
employees in developed countries can suffer human rights abuse in countries that have a strong institutional framework. We suggest further studies in this area.

\section{Insert figures 1, 2, 3, 4 and tables 4 and 5}

\section{Implications for policy and management decision making}

Our data shows that corporate political engagements that mostly undermines human rights violations usually go unpunished in most emerging economies. For example, there are instances where MNCs interfere in the politics of such countries either by financing or supporting military actions to overthrow democratically elected presidents (Collins, 2009). These acts do not only undermine the sovereignty of resource-rich emerging economies but also plunders most of the affected countries into a cycle of political and economic instability. We recommend that the level of publicness (Bozeman, 2013), transparency, and accountability of human rights violations (Wettstein, 2019) must be encouraged in all front. Thus, corporate engagements must be subjected to a higher level of accountability and scrutiny by a credible and nonpartisan independent audit and human rights advocacy groups.

Besides, MNCs operating in emerging economies must standardise their human resource (people) development programmes and training on health and safety procedures as part of their ethnocentric strategies during internationalisation. Further, MNCs must set the parameters and follow legislation that prevents human rights violations in emerging economies on issues regarding employee health and safety in host countries. In this regard, we propose that human rights protection Act, similar to the Health and Safety at Work (HASWA) Act 1974 should be adopted by all resource-rich emerging economies. The HASWA is a UK Act that defines the fundamental structures and authority for safeguarding workforce and preventing human rights 
violations. HASWA Act provides extensive coverage to all industries including supply chains and strategic business units of MNCs. An equivalent Act for all emerging economies, particularly the resource-rich ones could induce a system of independent public scrutiny and supervision through the creation of health and safety commission and health and safety executives backed by severe criminal sanctions including imprisonment for executives of MNCs operating in emerging economies who fail to protect their workforce. Whilst the territorial extent of HASWA Act 1974 only covers the UK, this study proposes a replication of this system across emerging economies similar to the International Standard Organisation certification and accreditation rules.

Our study reveals intriguing disparities between corporate human rights talk and corporate human rights walk. This revelation justifies the argument that MNCs exert pressure to influence ethical discourses and legitimacy tactics to their advantage. In some cases, government ministers even use the provision of employment argument to conceal the unethical practices of MNCs. We also recommend that the media should be empowered to scrutinise human rights violations and related activities to ensure fair and credible local discourse about supporting those affected. We advocate for government policy to implement the right to information (RTI) by supporting and empowering Non-Governmental Organisations (NGOs) and community groups to demand yearly statutory disclosure of human rights violations by MNCs rather than voluntary disclosures.

MNCs need to develop processes and systems that comply with the ten principles of the United Nations Global Compact (see Rasche et al., 2013). The ten principles cover four key issues including human rights, environmental issues, labour standards, and preventing corruption. Comprehensive guidance about how to implement and monitor the effectiveness of the above code should be put in place to ensure effective outcomes. Three main aspects of any organisation include people, processes and systems. These must be aligned in view of the 
contextual realities in host countries. We assert that staff training (people management), adoption of relevant global processes and systems that respond to local realities provides pragmatic collaborations and engagement by MNCs with local and international regulatory institutions. Besides, supporting the development of effective legal systems could ensure MNCs and the state work together to end human rights violations.

Our study seeks to encourage MNCs to adopt a corporate culture that respects human rights irrespective of the prevailing culture, beliefs, formal and informal institutions, among other local factors. Further, it will enable MNCs to adopt a baseline responsibility that is grounded in prudential risk management. More importantly, our work provides nations with the necessary monitoring and a basis to institute investigative mechanisms and the authority to impose hefty fines and sentences to executives of MNCs that violate the fundamental rights of their employees. Independent third parties (i.e. NGOs and civil society groups) should be given an independent role to monitor the activities of the state and MNCs and report on human rights violations freely. Finally, similar to the Corporate Governance Index (CGI) we propose that the introduction of an emerging market human rights index (EMHRI) would be the best starting point to monitor and report on the activities of MNCs operating in emerging economies. The results of this index could potentially influence the share prices of MNCs at the international level.

\section{Conclusion and avenues for future research}

This study explores the characteristics of MNCs that engage in human rights violations. We identified a total of 273 human rights violations between 2002 and 2017. Most of these violations occurred in developing countries by multinationals, the majority of whom are listed in developed countries. Using a content analysis approach and looking for specific media stories on further details about these violations, we found various categories of human rights 
violations, including poor working conditions, racial discrimination, land grab, harassment, child labour, abuse against female workers, and paying below the stipulated minimum wage. We also highlight that most of these violations occurred in the mining industry, which signifies the resources seeking motives of MNCs operating in the emerging economies (Dunning and Lundan, 2008).

Our results indicate that emerging economies are vulnerable to various forms of unethical activities, due to weak legal, institutional and regulatory systems (North, 1991). We find that almost every MNCs in our sample has developed a human rights' policy, except two. This raises doubts about the usefulness of human rights policies in these corporations. A growing number of incidences in MNCs reporting the highest level of compliance with CSR and ethicsrelated programmes imply that majority of these corporations apply a 'box-ticking' exercise to various forms of corporate regulations. Such a level of compliance is ineffective as it is not implemented in good spirit. Consequently, this study agrees with Muchlinski (2001), Giuliani and Macchi (2013) and Giuliani (2018) in re-echoing the concern that governments in emerging economies should implement legally binding corporate commitments in the observance of human rights as an important aspect of directors duties. Government policy should emphasise the importance of corporation's legal responsibility in resource-rich economies. As confirmed by our data, Dobers and Halme (2009) Ntim and Soobaroyen (2013), Frynas (2010) also agree that MNCs' commitment to their 'social' roles in local communities, particularly in emerging economies has always been used as an optional extra in their corporate strategy toolkit and adherence to informal rules and local institutions is pitiable in countries with weak regulatory systems.

In this regard, as Ghana has recently been chosen as the African regional trade capital which is currently the world's largest Free Trade Area (see Forbes, 2019), policymakers must convert 
this opportunity into a strong negotiating instrument to build stronger institutions aimed at regulating the activities of resource-seeking MNCs across Africa. In addition, BRICs countries need to assert their current position in world trade by supporting member countries in each subregion to develop comprehensive policies similar to the OECD guidelines for MNCs operating in these countries. This could support emerging economies to acquire and develop the skills and resources needed to regulate economic sectors and industries facing considerable human rights violations at the local level (Giuliani, 2016). Also, it is worth mentioning that, while violation of the law could have happened due to weak laws and institutions, these acts could have been disproportionately magnified to shame governments (Kahn-Nisser 2019). Previous empirical study such as Kahn-Nisser (2019) argues that US firms are more likely to suffer naming and shamming by international human rights activist and NGO's due to their significant voting rights at the UN general assembly on issues related to the Convention Against Torturing (CAT) (Kahn-Nisser 2019).

Future studies may investigate corporate disclosure documents to assess what responses and explanations MNCs report in disclosure documents once firm-specific scandal appears in the public domain. It would also be interesting to see how MNCs change their governance structures after a human rights violation. From a market-based accounting research perspective, future studies may examine the stock market reaction to different types of scandals (human rights, accounting, social, and environmental) to understand whether investors react differently to different types of scandals.

\section{References}

Abba, M., Said, R. M., Abdullah, A., \& Mahat, F., 2018. The Relationship Between Environment Operational Performance and Environmental Disclosure of Nigerian Listed Companies. $J$. Environ. Account. Manag. 6, 1-15.

Ackah-Baidoo, A., 2012. Enclave development and 'offshore corporate social responsibility': Implications for oil-rich sub-Saharan Africa. Resour. Policy, 37, 152-159. 
Adams, D., Adams, K., Ullah, S., \& Ullah, F., 2019. Globalisation, governance, accountability and the natural resource 'curse': Implications for socio-economic growth of oil-rich developing countries. Resour. Policy. 61, 128-140.

Adams, D., Ullah, S., Akhtar, P., Adams, K., \& Saidi, S., 2019. The role of country-level institutional factors in escaping the natural resource curse: Insights from Ghana. Resour. Policy. 61, 433440.

Adams, K., Debrah, Y. A., Williams, K., \& Mmieh, F., 2014. Causes of financial FDI inflows into subSaharan Africa (SSA): Evidence from Ghana. Thunderbird Int. Bus. Rev. 56, 439-459.

Adams, K., Debrah, Y. A., Williams, K., \& Mmieh, F., 2015. Why on earth should foreign banks invest in Africa's financial services sector? Evidence from financial multinationals in Ghana. Thunderbird Int. Bus. Rev. 57, 445-462.

Adams, K., Nayak, B. S., \& Koukpaki, S., 2018. Critical perspectives on "manufactured" risks arising from Eurocentric business practices in Africa. Crit. Perspect. Int. Bus. 14, 210-229.

Adams, K., Nyuur, R. B., Ellis, F. Y., \& Debrah, Y. A., 2017. South African MNCs' HRM systems and practices at the subsidiary level: Insights from subsidiaries in Ghana. J. Int. Manag. 23, 180193.

Adams, K., Nyuur, R., Chima, M., \& Debrah, Y., 2018. Offshore/nearshore outsourcing as a strategic competitive posturing: insights from Ghana. In 2018 Brit. Acad. Manag. Conference.

Adeola, F. O., 2005. Racial and class divergence in public attitudes and perceptions about poverty in USA: An empirical study. Race, Gender \& Class, 53-80.

Amaeshi, K. M., Osuji, O. K., \& Nnodim, P., 2008. Corporate social responsibility in supply chains of global brands: A boundaryless responsibility? J. Bus. Ethics. 81, 223-234.

Amaeshi, K., Adegbite, E., \& Rajwani, T., 2016. Corporate social responsibility in challenging and non-enabling institutional contexts: Do institutional voids matter?. J. Bus. Ethics. 134, 135153.

Asmussen, C. G., \& Fosfuri, A., 2019. Orchestrating corporate social responsibility in the multinational enterprise. Strategic Manage. J. 40, 894-916.

Assembly, U. G., 1948. Universal declaration of human rights. UN General Assembly, 302.

Awad, A., \& Ragab, H., 2018. The economic growth and foreign direct investment nexus: Does democracy matter? Evidence from African countries. Thunderbird Int. Bus. Rev, 60, 565-575.

Barraquier, A., 2011. Ethical behaviour in practice: Decision outcomes and strategic implications. Brit J. Manage. 22, S28-S46.

Barry, C.M., Chad Clay, K. and Flynn, M.E., 2013. Avoiding the spotlight: Human rights shaming and foreign direct investment. Int. Stud. Quart. 57, 532-544.

Beck, A.C., Campbell, D. and Shrives, P.J., 2010. Content analysis in environmental reporting research: Enrichment and rehearsal of the method in a British-German context. Brit. Account. Review. 42, 207-222. 
Belal, A. R., Cooper, S. M., \& Roberts, R. W., 2013. Vulnerable and exploitable: The need for organisational accountability and transparency in emerging and less developed economies. Account. Forum, 37, 81-91.

Bozeman, B., 2013. What organization theorists and public policy researchers can learn from one another: Publicness theory as a case-in-point. Organi. Stud. 34, 169-188.

Braithwaite, J., 2006. Responsive regulation and developing economies. World Dev. 34, 884-898.

Brewster, C., Wood, G., \& Brookes, M., 2008. Similarity, isomorphism or duality? Recent survey evidence on the human resource management policies of multinational corporations. Brit. J. Manage. 19, 320-342.

Buckley, P. J., Doh, J. P., \& Benischke, M. H., 2017. Towards a renaissance in international business research? Big questions, grand challenges, and the future of IB scholarship. J. Int. Bus. Stud. 48, 1045-1064.

Buckley, P. J., Enderwick, P., \& Cross, A. R., 2018 Int. Bus. Oxford University Press.

Cohen, M., 2020. Doing business abroad: a review of selected recent Canadian case-studies on corporate accountability for foreign human rights violations. Int. J. Hum. Rights, 1-16.

Collins, D., 2009. The failure of a socially responsive gold mining MNC in El Salvador: Ramifications of NGO mistrust. J. Bus. Ethics, 88, 245-268.

Collinson, S., Narula, R., \& Rugman, A. M., 2016. Int. bus. Pearson.

Cooper, C., Coulson, A., \& Taylor, P., 2011. Accounting for human rights: Doxic health and safety practices-The accounting lesson from ICL. Crit. Perspect. Accoun. 22, 738-758.

Crane, A., Matten, D., \& Spence, L. (Eds.)., 2019. Corporate social responsibility: Readings and cases in a global context. Routledge.

De Soysa, I., \& Vadlamannati, K. C., 2011. Does being bound together suffocate, or liberate? The Effects of economic, Social, and Political Globalization on Human Rights, 19812005. Kyklos, 64, 20-53.

Dentoni, D., Bitzer, V., \& Schouten, G., 2018. Harnessing wicked problems in multi-stakeholder partnerships. J. Bus. Ethics. 150, 333-356.

DiMaggio, P. J., \& Powell, W. W., 1983. The iron cage revisited: Institutional isomorphism and collective rationality in organizational fields. Am. Social. Rev. 147-160.

Dobers, P., \& Halme, M., 2009. Corporate social responsibility and developing countries. Corp Soc Resp. Env. Ma. 16, 237-249.

Du, S., \& Vieira, E. T. (2012). Striving for legitimacy through corporate social responsibility: Insights from oil companies. J. Bus. Ethics, 110, 413-427.

Duke, J., 2020. Enforcement of Human Rights on Multi-National Corporations: Global Climate, Strategies and Trends for Compliance. Denver J. Int. Law Pol. $28,2$.

Dunning, J. H., 1998. Location and the multinational enterprise: a neglected factor?. J. Int. Bus. Stud. 29, 45-66. 
Dunning, J. H.,m 2001. The eclectic (OLI) paradigm of international production: past, present and future. Int. J. Econ. Bus. 8, 173-190.

Dunning, J. H., 2006. Towards a new paradigm of development: implications for the determinants of international business. Transnat. Corp. 15, 173-227.

Dunning, J. H., \& Lundan, S. M., 2008. Multinational enterprises and the global economy. Edward Elgar Publishing.

Edwards, T., \& Ferner, A., 2002. The renewed 'American Challenge': A review of employment practice in US multinationals. Ind. Rel. J. 33, 94-111.

Edwards, T., Marginson, P., \& Ferner, A., 2013. Multinational Companies in Cross-National Context: Integration, Differentiation, and the Interactions between MNCS and Nation States: Introduction to a Special Issue of the ILR Review, 66, 547-587.

Fatehi, K., \& Choi, J., 2019. International Management and the Cultural Context. In Int. Bus. Manage. 77-108. Springer, Cham.

Feenstra, R. C., \& Hanson, G. H., 1996. Globalization, outsourcing, and wage inequality (No. w5424). National Bureau of Economic Research.

Financial Times., 2017. Special Report: Tighter standards of conduct for supply chains. Retrieved from https://www.ft.com/content/d4b05aae-af83-11e 7-8076-0a4bdda92ca2 accessed on 13/04/19

Flanagan, R. J., 2006. Globalization and labor conditions: working conditions and worker rights in a global economy. Oxford University Press.

Forbes., 2019. Ghana Hopes To Benefit From Hosting Africa's Free Trade Area Secretariat. Retrieved from https://www.forbesafrica.com/travel/2019/07/23/ghana-hopes-to-benefit-from-hostingafricas-free-trade-area-secretariat/ on 16/08/20

Forsgren, M., \& Holm, U., 2010. MNC headquarters' role in subsidiaries' value-creating activities: A problem of rationality or radical uncertainty. Scand. J. Manag. 26, 421-430.

Freer, J., 2017. Sustainable development goals and the human resource crises, Int. Health, 9: 1-2.

Friedman, M., 2007. The social responsibility of business is to increase its profits. In Corporate ethics and corporate governance 173-178. Springer, Berlin, Heidelberg.

Frynas, J. G., 2010. Corporate social responsibility and societal governance: Lessons from transparency in the oil and gas sector. J. Bus. Ethics, 93, 163-179.

Giuliani, E., 2016. Human rights and corporate social responsibility in developing countries' industrial clusters. J. Bus. Ethics, 133, 39-54.

Giuliani, E., 2018. Why multinational enterprises may be causing more inequality than we think. Multinatl. Bus. Rev. 221-225

Giuliani, E., \& Macchi, C., 2013. Multinational corporations' economic and human rights impacts on developing countries: a review and research agenda. Camb. J. Econ. 38, 479-517.

Hill, C. W. L., 2007. International Business: Competing in the Global Market, $5^{\text {th }}$ Edition, McGraw Hill, New York 
Hinings, C. R., \& Greenwood, R., 2002. ASQ Forum: Disconnects and Consequences in Organization Theory?. Admin. Sci. Quart. 47, 411-421.

Hofstede, G., 1984. Cultural dimensions in management and planning. Asia Pac. J. Manag. 1, 81-99.

Hoskisson, R. E., Eden, L., Lau, C. M., \& Wright, M., 2000. Strategy in emerging economies. Acad. of Manage. J. 43, 249-267.

Hoskisson, R. E., Wright, M., Filatotchev, I., \& Peng, M. W., 2013. Emerging multinationals from midrange economies: The influence of institutions and factor markets. J. Manage. Stud. 50, 12951321.

Jamali, D., \& Karam, C., 2018. Corporate social responsibility in developing countries as an emerging field of study. Int. J. Manag. Rev. 20, 32-61.

Jauernig, J., \& Valentinov, V., 2019. CSR as hypocrisy avoidance: a conceptual framework. Sustain. Account. Manag. Policy J. 10, 2-25.

Jensen, M. C., \& Meckling, W. H., 1976. Theory of the firm: Managerial behavior, agency costs and ownership structure. J. Financ. Econ. 3, 305-360.

Johanson, J., \& Vahlne, J. E., 1977. The internationalization process of the firm-a model of knowledge development and increasing foreign market commitments. J. Int. Bus. Stud. 8, 23-32.

Jones, T. M., 1995. Instrumental stakeholder theory: A synthesis of ethics and economics. Acad. Manage. Rev. 20, 404-437.

Kahn-Nisser, S., 2019. When the targets are members and donors: Analyzing inter-governmental organizations' human rights shaming. Rev. Int. Organ. 14, 431-451.

Kano, L., \& Verbeke, A., 2019. Theories of the multinational firm: A micro-foundational perspective. Glob Strateg. J. 9, 117-147.

Kaufman, B. E., 2016. Globalization and convergence-divergence of HRM across nations: New measures, explanatory theory, and non-standard predictions from bringing in economics. Hum Resour. Manage. R. 26, 338-351.

Kaufmann, W., Hooghiemstra, R., \& Feeney, M. K., 2018. Formal institutions, informal institutions, and red tape: A comparative study. Public Admin. 96, 386-403.

Kostova, T., 1997. Country institutional profiles: Concept and measurement. Acad. Manage. Proc. 97, 180-184

Lauwo, S., \& Otusanya, O. J., 2014. Corporate accountability and human rights disclosures: A case study of Barrick Gold Mine in Tanzania. Account. Forum, 38, 91-108.

Mallin, A. C., 2019. Corporate governance. Sixth edition. Oxford University Press

Marano, V., Tashman, P., \& Kostova, T., 2017. Escaping the iron cage: Liabilities of origin and CSR reporting of emerging market multinational enterprises. J. Int. Bus. Stud. 48, 386-408.

Maslow, A. H., 1943. A theory of human motivation. Psychol. Rev. 50, 370.

Merkl-Davies, D. M., Brennan, N. M., \& McLeay, S. J., 2011. Impression management and retrospective sense-making in corporate narratives: A social psychology perspective. Account. Audit Account. Journal, 24, 315-344. 
Meyer, K. E., \& Grosse, R., 2018. Introduction to managing in emerging markets. In The Oxford Handbook of Management in Emerging Markets.

Meyer, K. E., Mudambi, R., \& Narula, R., 2011. Multinational enterprises and local contexts: The opportunities and challenges of multiple embeddedness. J. Manage. Stud. 48, 235-252.

Monshipouri, M., Welch, C. E. and Kennedy, E. T., 2003. Multinational corporations and the ethics of global responsibility: problems and possibilities, Hum. Rights Quart. 25, 965-89

Muchlinski, P. T., 2001. Human rights and multinationals: is there a problem?. Int. Aff. 77, 31-47.

Nieri, F., \& Giuliani, E., 2018. International Business and Corporate Wrongdoing: A Review and Research Agenda. In Contemporary Issues in Int. Bus. 35-53. Palgrave Macmillan, Cham.

North, D. C., 1991. Institutions. J. Econ. Perspect. 5, 97-112.

Ntim, C. G., \& Soobaroyen, T., 2013. Corporate governance and performance in socially responsible corporations: New empirical insights from a neo-institutional framework. Corp. Gov. 21, 468494.

O'manique, J., 1992. Human rights and development. Hum. Rights Quart. 14, 78.

Osabutey, E. L., Williams, K., \& Debrah, Y. A., 2014. The potential for technology and knowledge transfers between foreign and local firms: A study of the construction industry in Ghana. $J$. World Bus. 49, 560-571.

Peteraf, M. A., 1993. The cornerstones of competitive advantage: a resource-based view. Strateg. Manage. J. 14, 179-191.

Prahalad, C. K., 2009. The fortune at the bottom of the pyramid, revised and updated 5th anniversary edition: Eradicating poverty through profits. FT Press.

Pudelko, M., 2005. Cross-national learning from best practice and the convergence-divergence debate in HRM. The Int. J. Hum. Resour. Man. 16, 2045-2074.

Rasche, A., Waddock, S., \& McIntosh, M., 2013. The United Nations global compact: Retrospect and prospect. Bus. Soc. 52, 6-30.

Rodrik, D., 2017. Straight Talk on Trade: Ideas for a Sane World Economy, Princeton University Press, Princeton, NJ.

Rudkin, B., Kimani, D., Ullah, S., Ahmed, R. and Farooq, S.U., 2019. Hide-and-seek in corporate disclosure: evidence from negative corporate incidents. Corp. Gov: The International Journal of Bus. in Soc., 19,158-175.

Ruggie, J. G., 2007. Business and human rights: the evolving international agenda. Am. J. Int. Law, 101, 819-840.

Rugman A. M. \& Collinson S., 2006. International Business ( $4^{\text {th }}$ Edition), Pearson Education, Harlow, UK

Rugman, A. M. \& Verbeke, A., 2004. A perspective on regional and global strategies of multinational enterprises J. Int. Bus. Stud. 35, 3-18

Santoro, M. A., 2015. Business and human rights in historical perspective. J. Hum. Rights, 14, 155-161. 
Sarpong, D., Sajdakova, J., \& Adams, K., 2019. The Mabey and Johnson bribery scandal: A case of executive hubris. Thunderbird Int. Bus. Rev. 61, 387-396.

Scholte, J. A., 2007. Civil society and the legitimation of global governance. J. Civ. Soc. 3, 305-326.

Shi, J., 2019. Vertical FDI and exchange rates over the business cycle: The welfare implications of openness to FDI. J. Dev. Econ. 138, 274-293.

Short, K. S., 2005. Material and financial hardship and income-based poverty measures in the USA. $J$. Soc. Policy, 34, 21-38.

Sikka, P., 2010. Smoke and mirrors: Corporate social responsibility and tax avoidance. Account. Forum, $34,153-168$.

Sikka, P., 2011. Accounting for human rights: The challenge of globalisation and foreign investment agreements. Crit. Perspect. Account. 22, 811-827.

Stiglitz, J. E., 2006. Making Globalization Work, W.W. Norton and Co, New York, NY.

Strange, R., \& Magnani, G., 2017. The performance consequences of manufacturing outsourcing: Review and recommendations for future research. In Breaking up the Global Value Chain: Opportunities and Consequences, 217-244. Emerald Publishing Limited.

Tashman, P., Marano, V., \& Kostova, T., 2019. Walking the walk or talking the talk? Corporate social responsibility decoupling in emerging market multinationals. J. Int. Bus. Stud. 50, 153-171.

Trompenaars, F., \& Hampden-Turner, C., 1998. Riding the waves of culture. New York: McGrawHill.

Tung, R. L., \& Stahl, G. K., 2018. The tortuous evolution of the role of culture in IB research: What we know, what we don't know, and where we are headed. J. Int. Bus. Stud. 49, 1167-1189.

Ullah, S., Ahmad, S., Akbar, S., \& Kodwani, D., 2018. International evidence on the determinants of organizational ethical vulnerability. Brit. J. Manage. 30, 668-691

Unerman, J., 2000. Methodological issues-Reflections on quantification in corporate social reporting content analysis. Account. Audit Account. J. 13, pp.667-681.

United Nations Working Group on Business and Human Rights, 2017. Protect, respect and remedy. UN Human Rights, Office of the High Commissioner, Geneva(2017). Retrieved from https://www.ohchr.org/Documents/Issues/Business/Session18/InfoNoteWGBHR_SDGRecom mendations.pdf. Accessed on April 10, 2019

Verbeke, A., \& Greidanus, N., 2012. The end of the opportunism versus trust debate: Bounded reliability as a new envelope concept in research on MNE governance. In Handbook of Research on International Strategic Management. Edward Elgar Publishing.

Vivoda, V., \& Kemp, D., 2019. How do national mining industry associations compare on sustainable development? Extr. Ind. Soc. 6, 22-28.

Vourvachis, P., Woodward, T., Woodward, D. G., \& Patten, D. M., 2016. CSR disclosure in response to major airline accidents: a legitimacy-based exploration. Sustain. Account. Manag. Policy J. 7, 26-43. 
Wagner, T., Lutz, R. J., \& Weitz, B. A., 2009. Corporate hypocrisy: Overcoming the threat of inconsistent corporate social responsibility perceptions. J. Market. 73, 77-91.

Wettstein, F., Giuliani, E., Santangelo, G. D., \& Stahl, G. K., 2019. International business and human rights: A research agenda. J. World Bus. 54, 54-65.

Williamson, O. E., 1993. Transaction cost economics meets posnerian law and economics. Journal of Institutional and Theoretical Economics (JITE)/Zeitschrift für die gesamte Staatswissenschaft, 149, 99-118.

Worster, W. T., 2020. Al Jazeera at the International Court of Justice: Protecting Media Corporations Under Human Rights Law. Available at SSRN 3528221.

Zhang, Y., \& Zhang, S., 2018. The impacts of GDP, trade structure, exchange rate and FDI inflows on China's carbon emissions. Energ. policy, 120, 347-353. 
Table 1: Incidences of Human rights violations by Multinational corporations between 2002 \& 2017

\begin{tabular}{|c|c|c|c|}
\hline $\begin{array}{l}\text { MNCs country of } \\
\text { origin }\end{array}$ & No of Industries & No of MNCs & $\begin{array}{l}\text { No. of human right } \\
\text { violations }\end{array}$ \\
\hline Australia & 4 & 6 & 20 \\
\hline Austria & 1 & 1 & 1 \\
\hline Belgium & 1 & 1 & 1 \\
\hline Brazil & 2 & 2 & 9 \\
\hline Canada & 5 & 6 & 16 \\
\hline China & 2 & 3 & 6 \\
\hline Denmark & 2 & 2 & 2 \\
\hline Finland & 2 & 2 & 2 \\
\hline France & 5 & 5 & 10 \\
\hline Germany & 5 & 6 & 9 \\
\hline Hong Kong & 3 & 2 & 2 \\
\hline India & 3 & 3 & 3 \\
\hline Italy & 2 & 2 & 2 \\
\hline Japan & 9 & 13 & 14 \\
\hline Malaysia & 1 & 1 & 1 \\
\hline Russia & 2 & 2 & 2 \\
\hline Spain & 1 & 1 & 1 \\
\hline Singapore & 1 & 1 & 1 \\
\hline Sweden & 4 & 5 & 5 \\
\hline Thailand & 1 & 1 & 1 \\
\hline Switzerland & 5 & 5 & 11 \\
\hline South Africa & 2 & 2 & 5 \\
\hline United States & 44 & 68 & 88 \\
\hline United Kingdom & 13 & 20 & 61 \\
\hline Total & & 160 & 273 \\
\hline
\end{tabular}


Table 2: Examples of human right violations based on country of origin of MNCs and the location of incidents

\begin{tabular}{|c|c|c|c|c|c|}
\hline MNC & $\begin{array}{l}\text { Country of } \\
\text { Origin }\end{array}$ & Industry & Country of incident & Type of Human right violation & Case investigation/Outcome \\
\hline $\begin{array}{l}\text { AUS. AND NZ. } \\
\text { BANKING GP. }\end{array}$ & $\begin{array}{l}\text { AUSTRALI } \\
\text { A }\end{array}$ & Banks & Cambodia & $\begin{array}{l}681 \text { families who were forcibly displaced and } \\
\text { dispossessed of their land }\end{array}$ & $\begin{array}{l}\$ 5,750,000 \text { fine paid to The } \\
\text { Office of Foreign Assets } \\
\text { Control }\end{array}$ \\
\hline BHP BILLITON & $\begin{array}{l}\text { AUSTRALI } \\
\text { A }\end{array}$ & $\begin{array}{l}\text { General } \\
\text { Mining }\end{array}$ & Colombia & $\begin{array}{l}\text { Forcibly expelling the remaining population } \\
\text { through a purported expropriation }\end{array}$ & NA \\
\hline RIO TINTO & $\begin{array}{l}\text { AUSTRALI } \\
\text { A }\end{array}$ & $\begin{array}{l}\text { General } \\
\text { Mining }\end{array}$ & $\begin{array}{l}\text { Mongolia, Papua } \\
\text { New Guinea }\end{array}$ & $\begin{array}{l}\text { Racial discrimination against its black workers at } \\
\text { Panguna }\end{array}$ & $\begin{array}{l}\text { Banned from The Government } \\
\text { Pension Fund of Norway }\end{array}$ \\
\hline OMV & AUSTRIA & $\begin{array}{l}\text { Integrated Oil } \\
\& \text { Gas }\end{array}$ & Sudan & Human right in conflict zones & NA \\
\hline JBS ON & BRAZIL & $\begin{array}{l}\text { Food } \\
\text { Products }\end{array}$ & Brazil & $\begin{array}{l}\text { Meat producing company, serving its employees } \\
\text { maggot-infested meat }\end{array}$ & $\mathrm{R} \$ 2.3$ million penalty \\
\hline $\begin{array}{l}\text { BARRICK GOLD } \\
\text { (NYS) }\end{array}$ & $\begin{array}{l}\text { UNITED } \\
\text { STATES }\end{array}$ & Gold Mining & Papua New Guinea & $\begin{array}{l}\text { Killings by security guards at the Porgera Joint } \\
\text { Venture (PJV) mine }\end{array}$ & NA \\
\hline GOLDCORP (NYS) & $\begin{array}{l}\text { UNITED } \\
\text { STATES }\end{array}$ & Gold Mining & $\begin{array}{l}\text { Mexico, Marlin } \\
\text { Mine, }\end{array}$ & Basic Work Conditions, health & Ordered to shut operation \\
\hline $\begin{array}{l}\text { HUDBAY } \\
\text { MINERALS }\end{array}$ & CANADA & $\begin{array}{l}\text { Nonferrous } \\
\text { Metals }\end{array}$ & Guatemala, Mexico & $\begin{array}{l}\text { Human right abuses by mine security personnel } \\
\text { (gang rape incidents, sexual violence against } \\
\text { indigenous women) }\end{array}$ & $\begin{array}{l}\text { Judge ruled that parent } \\
\text { company can be held } \\
\text { responsible for the crime of its } \\
\text { subsidiary }\end{array}$ \\
\hline $\begin{array}{l}\text { NEVSUN } \\
\text { RESOURCES }\end{array}$ & CANADA & $\begin{array}{l}\text { General } \\
\text { Mining }\end{array}$ & Eritrea & $\begin{array}{l}\text { Three refugees who alleged they were forced to } \\
\text { work at Bisha mine } \\
\text { and endured harsh conditions and physical } \\
\text { punishment }\end{array}$ & $\begin{array}{l}\text { A court in the province of } \\
\text { British Columbia ruled that it } \\
\text { could be heard in the Canadian } \\
\text { legal system }\end{array}$ \\
\hline OCEANAGOLD & CANADA & Gold Mining & Philippine & Bribery, intimidation, harassment & $\begin{array}{l}\text { Licence revoked/Suspension of } \\
\text { Operation }\end{array}$ \\
\hline $\begin{array}{l}\text { TAHOE } \\
\text { RESOURCES }\end{array}$ & CANADA & Gold Mining & Guatemala, Mexico & $\begin{array}{l}\text { Firing by company's security personal at Peaceful } \\
\text { demonstration }\end{array}$ & $\begin{array}{l}\text { L+G15icenced revoked by } \\
\text { local court/Supreme Court of } \\
\text { Canada declined to hear Tahoe } \\
\text { Resources' appeal, clearing the }\end{array}$ \\
\hline
\end{tabular}




\begin{tabular}{|c|c|c|c|c|c|}
\hline & & & & & $\begin{array}{l}\text { way for the case to be tried in } \\
\text { Canada }\end{array}$ \\
\hline PETROCHINA 'A' & CHINA & $\begin{array}{l}\text { Integrated Oil } \\
\& \text { Gas }\end{array}$ & Sudan & $\begin{array}{l}\text { Supporting local government and operating in a } \\
\text { conflict zone }\end{array}$ & $\begin{array}{l}\text { US pensions and endowments } \\
\text { began divesting }\end{array}$ \\
\hline $\begin{array}{l}\text { ZIJIN MINING } \\
\text { GROUP 'A' }\end{array}$ & CHINA & Gold Mining & Papua New Guinea & $\begin{array}{l}\text { Abuse against women (by company's security } \\
\text { guard) }\end{array}$ & NA \\
\hline ABB LTD N & $\begin{array}{l}\text { SWITZERL } \\
\text { AND }\end{array}$ & $\begin{array}{l}\text { Industrial } \\
\text { Machinery }\end{array}$ & Sudan & $\begin{array}{l}\text { Forced relocation and violent interaction with } \\
\text { fatal outcomes }\end{array}$ & $\begin{array}{l}\text { Suspension of further business } \\
\text { activities }\end{array}$ \\
\hline $\begin{array}{l}\text { CREDIT SUISSE } \\
\text { GROUP N }\end{array}$ & $\begin{array}{l}\text { SWITZERL } \\
\text { AND }\end{array}$ & Banks & Cambodia & Land grab & NA \\
\hline NESTLE 'R' & $\begin{array}{l}\text { SWITZERL } \\
\text { AND }\end{array}$ & $\begin{array}{l}\text { Food } \\
\text { Products }\end{array}$ & Thailand & Employment of child labour & NA \\
\hline ADIDAS & GERMANY & Footwear & Cambodia & $\begin{array}{l}\text { Forced overtime, firing of pregnant women, } \\
\text { underage labour }\end{array}$ & NA \\
\hline BAYER & GERMANY & $\begin{array}{l}\text { Speciality } \\
\text { Chemicals }\end{array}$ & NA & $\begin{array}{l}\text { Violating international human right law (reliance } \\
\text { on the sale and use of dangerous and unsafe } \\
\text { pesticides including endosulfan, paraquat } \\
\text { and neonicotinoids) }\end{array}$ & NA \\
\hline BMW & GERMANY & Automobiles & India & Child labour & NA \\
\hline THYSSENKRUPP & GERMANY & $\begin{array}{l}\text { Divers. } \\
\text { Industrials }\end{array}$ & $\begin{array}{l}\text { Democratic Republic } \\
\text { of Congo }\end{array}$ & Conflict minerals & NA \\
\hline REPSOL YPF & SPAIN & $\begin{array}{l}\text { Integrated Oil } \\
\& \text { Gas }\end{array}$ & $\begin{array}{l}\text { Argentina, Bolivia \& } \\
\text { Ecuador }\end{array}$ & $\begin{array}{l}\text { Discrimination, violating the Right of Indigenous } \\
\text { Peoples }\end{array}$ & NA \\
\hline STORA ENSO 'R' & FINLAND & Paper & Brazil & $\begin{array}{l}\text { Limiting water availability in the communities } \\
\text { close to their plantations }\end{array}$ & NA \\
\hline WARTSILA & FINLAND & $\begin{array}{l}\text { Industrial } \\
\text { Machinery }\end{array}$ & India & Below minimum wage payment & NA \\
\hline
\end{tabular}


Table 3: Further analysis of corporate compliance with CSR/sustainability and commitments to business ethics and international human right regulations

\begin{tabular}{|c|c|c|c|c|c|c|c|}
\hline MNC & $\begin{array}{c}\text { CSR/Sustainability } \\
\text { Committee }\end{array}$ & $\begin{array}{c}\text { UN Global } \\
\text { Compact } \\
\text { Signatory } \\
\end{array}$ & $\begin{array}{c}\text { Member of } \\
\text { Ethical Trading } \\
\text { Initiative } \\
\end{array}$ & $\begin{array}{c}\text { MNC } \\
\text { reports UN ILO } \\
\text { compliance } \\
\end{array}$ & $\begin{array}{c}\text { Has a } \\
\text { Human } \\
\text { Rights } \\
\text { Policy } \\
\end{array}$ & $\begin{array}{l}\text { Discloses Explicit } \\
\text { Commitment to } \\
\text { Business Ethics }\end{array}$ & $\begin{array}{c}\text { Publishes Policy } \\
\text { on } \\
\text { Whistleblower } \\
\text { Protection } \\
\end{array}$ \\
\hline AUS. AND NZ. BANKING GP. & Yes & Yes & No & Yes & Yes & Yes & Yes \\
\hline BHP BILLITON & Yes & Yes & No & Yes & Yes & Yes & Yes \\
\hline RIO TINTO & Yes & Yes & No & Yes & Yes & Yes & Yes \\
\hline OMV & Yes & Yes & No & Yes & Yes & Yes & Yes \\
\hline JBS ON & Yes & No & No & No & Yes & Yes & Yes \\
\hline BARRICK GOLD (NYS) & Yes & Yes & No & Yes & Yes & Yes & Yes \\
\hline GOLDCORP (NYS) & Yes & Yes & No & Yes & Yes & Yes & Yes \\
\hline HUDBAY MINERALS & Yes & No & No & No & Yes & Yes & Yes \\
\hline NEVSUN RESOURCES & Yes & No & No & No & Yes & Yes & Yes \\
\hline OCEANAGOLD & Yes & No & No & Yes & Yes & Yes & Yes \\
\hline TAHOE RESOURCES & Yes & Yes & No & Yes & Yes & Yes & Yes \\
\hline PETROCHINA 'A' & Yes & Yes & No & No & Yes & Yes & Yes \\
\hline ZIJIN MINING GROUP 'A' & Yes & No & No & No & No & No & Yes \\
\hline ABB LTD N & Yes & Yes & No & Yes & Yes & Yes & Yes \\
\hline CREDIT SUISSE GROUP N & Yes & Yes & No & Yes & Yes & Yes & Yes \\
\hline NESTLE 'R' & Yes & Yes & No & Yes & Yes & Yes & Yes \\
\hline ADIDAS & Yes & No & No & Yes & Yes & Yes & Yes \\
\hline BAYER & Yes & Yes & No & Yes & Yes & Yes & Yes \\
\hline BMW & Yes & Yes & No & Yes & Yes & Yes & Yes \\
\hline THYSSENKRUPP & Yes & Yes & No & Yes & Yes & Yes & Yes \\
\hline REPSOL YPF & Yes & Yes & No & Yes & Yes & Yes & Yes \\
\hline STORA ENSO 'R' & Yes & Yes & No & Yes & Yes & Yes & Yes \\
\hline WARTSILA & Yes & Yes & No & Yes & Yes & Yes & Yes \\
\hline
\end{tabular}

Table 3 reports whether each company in our sample, having a human right incident has: (a) CSR/sustainability committee; (b) has signed United Nations

Global Compact on Human Rights; (c) is member of the Ethical Trading Initiative; (d) reported compliance with ILO (International Labour Organisation); (e)

has a human rights policy; (f) discloses explicit commitment to business ethics; and (g) has a clear protection policy for Whistleblowers. 
Figure 1: A comparative bar graph showing level of compliance with human rights by MNC's operating in developing and emerging economies

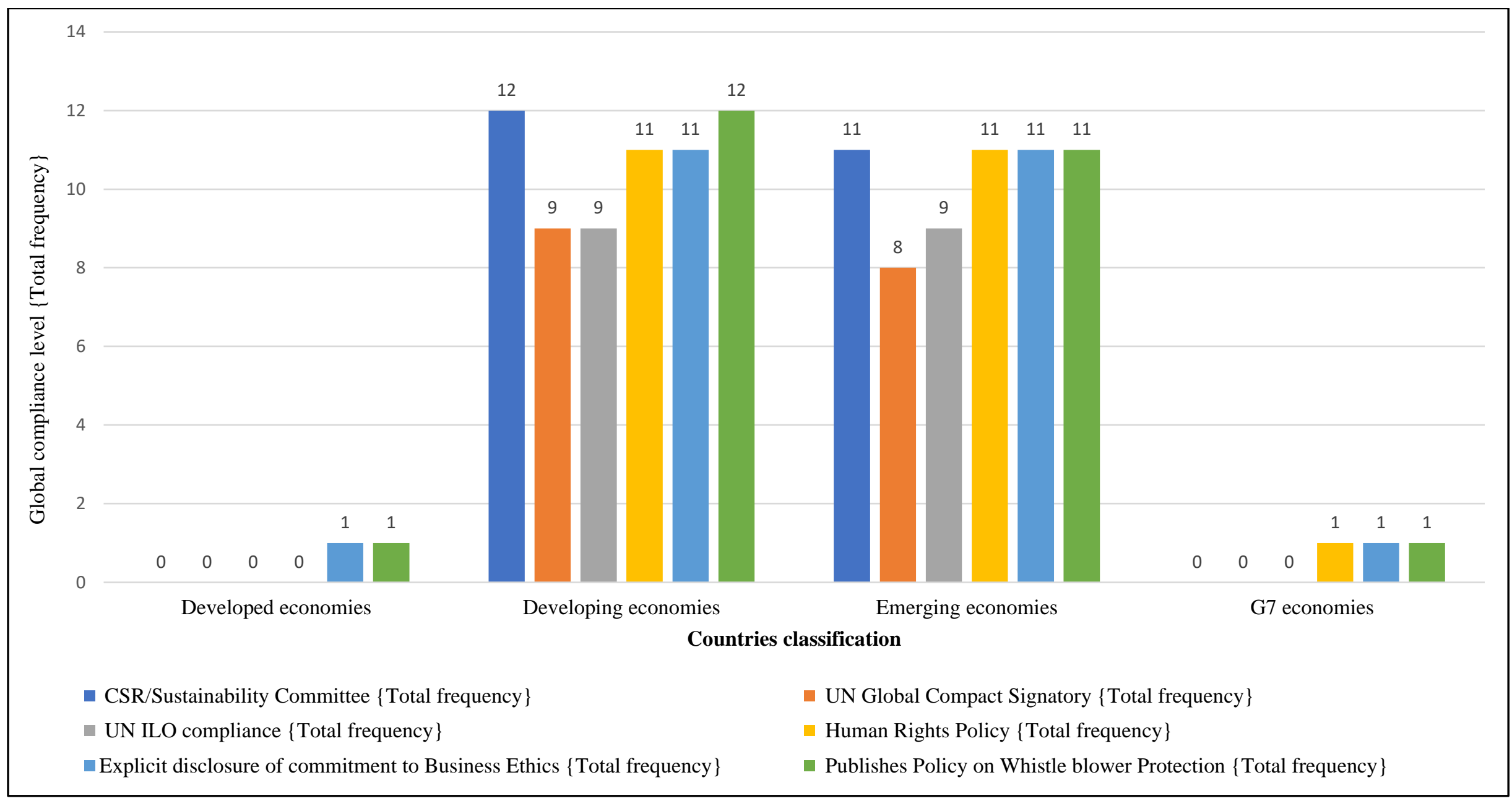

Note: This frequency analysis is based on Table 3 which uses a combination of accumulated firm-level and institutional data between $2002-2017$ 
Figure 2: A Bar graphs showing the ranking order of compliance with human rights by MNC's operating in emerging economies

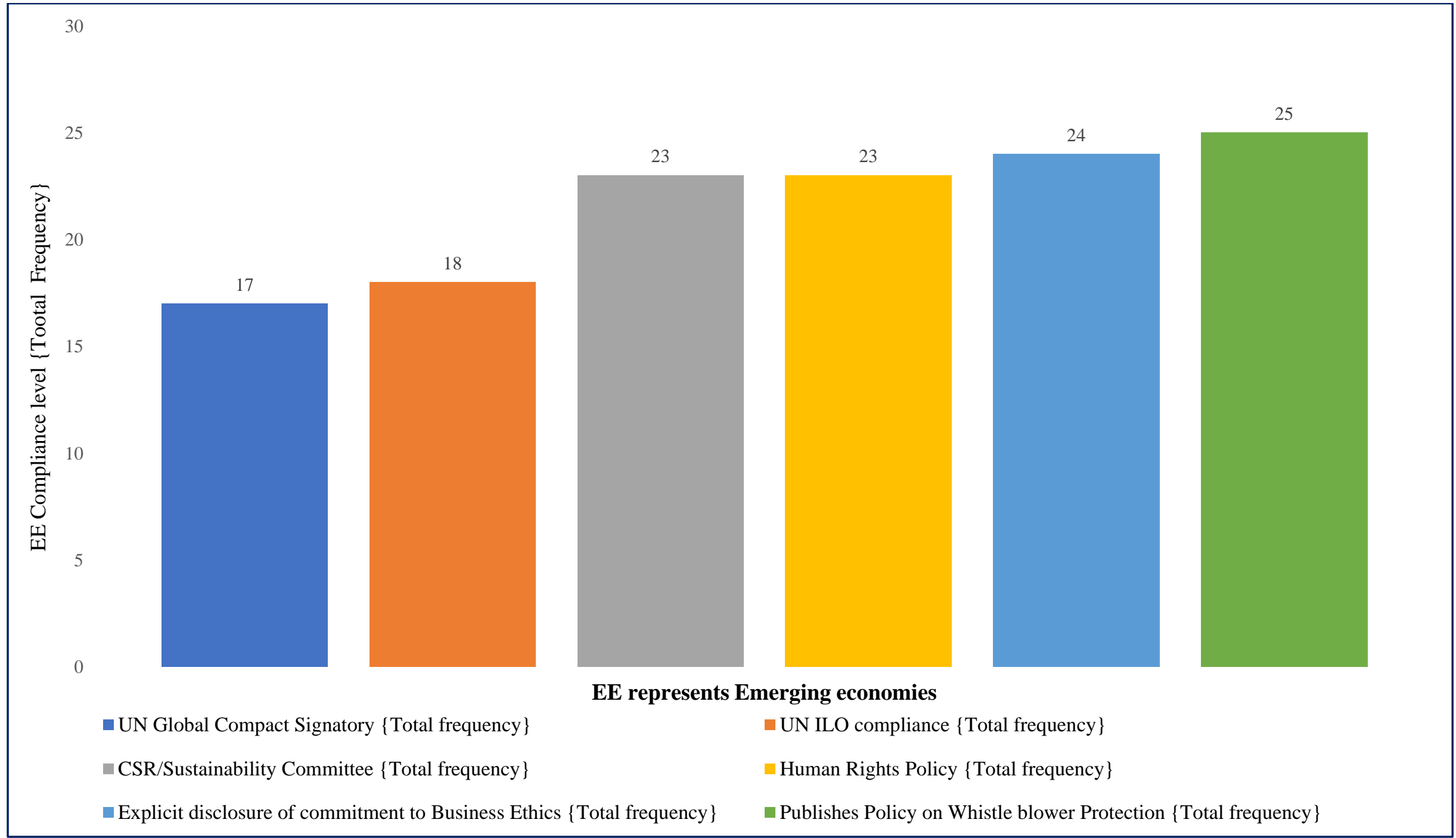

Note: This frequency analysis based on Table 3 uses a combination of accumulated firm-level and institutional data between $2002-2017$ 
Figure 3: A line graph showing level of compliance with human rights by MNC's operating in developing and emerging countries
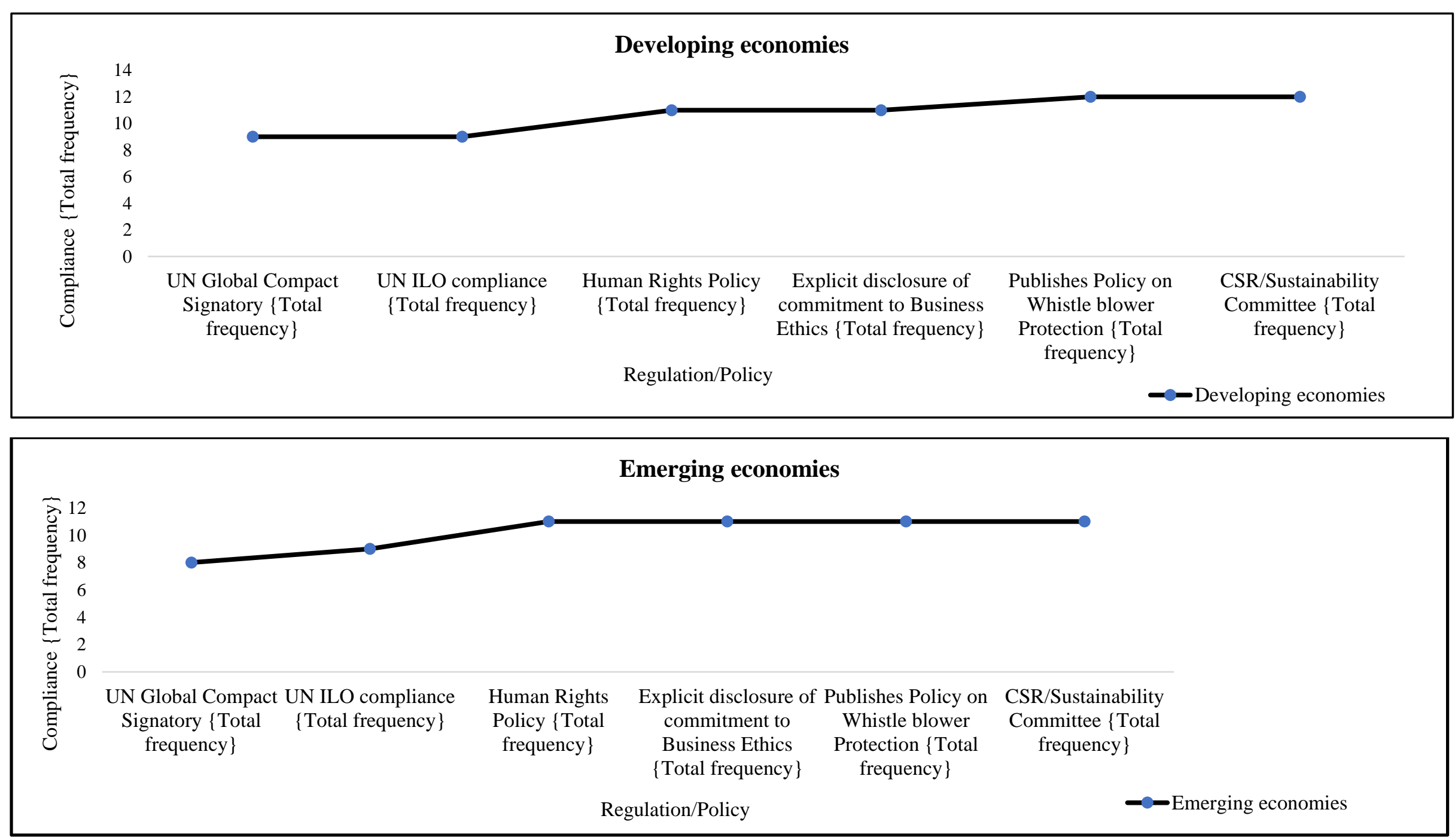

Note: This frequency analysis based on Table 3 uses a combination of accumulated firm-level and institutional data between $2002-2017$ 
Figure 4: Standardised Quantile-Quantile plot showing human rights score between the investing country, domestic country for the

\section{USA and the UK}

Parent/foreign country- Human rights score
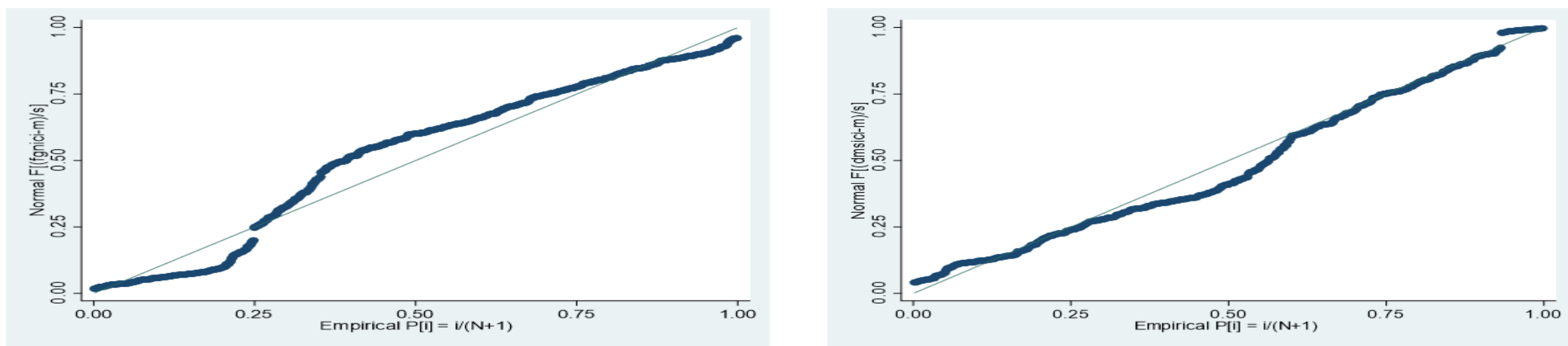

US- Human rights score

UK- Human rights score
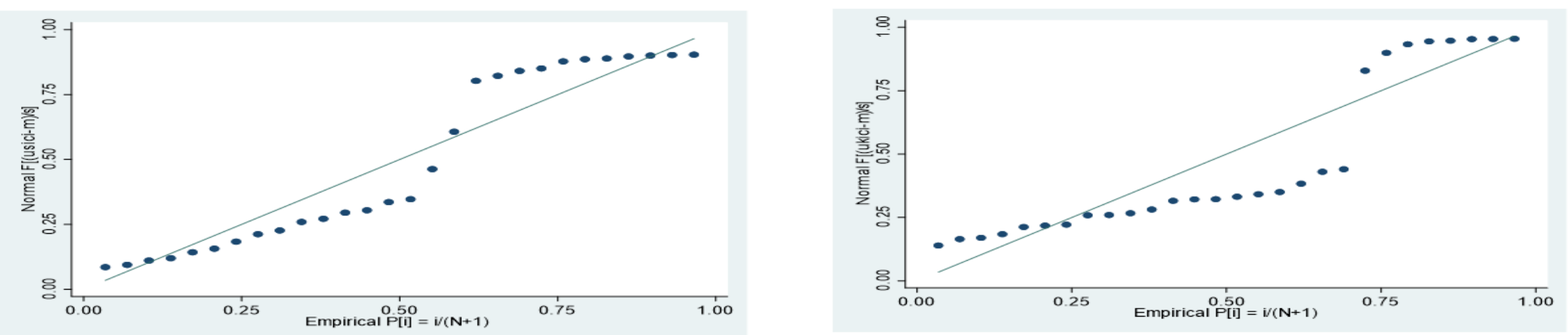

Note: We used a standardised Quantile-quantile plot (Q-Q Plot) to capture the excesses of human rights abuse between 1990 -2017 by the parent/foreign country, domestic countries, USA and the UK. The standardised normal quantities-quantile plot shows human rights scores from UK and US in some instances deviates from the expected global human rights score. Our results compare the observed cumulative distribution function (CFD) of the standardised residuals to the expected CDF of the normal distribution. Above results imply possible human rights violations even in developed countries such as the UK and US. The results from the above Q-Q plot shows that the human rights scores for US and UK are far below the 5.4 which is the global expected highest score according to the global human rights index database. 
Table 4: Frequency table showing compliance with the six human rights initiatives.

\begin{tabular}{|c|c|c|c|c|c|c|}
\hline Country & $\begin{array}{c}\text { UN Global Compact } \\
\text { Signatory } \\
\{\text { Total frequency }\}\end{array}$ & $\begin{array}{c}\text { UN ILO } \\
\text { compliance } \\
\{\text { Total } \\
\text { frequency } \\
\end{array}$ & $\begin{array}{c}\text { Human Rights } \\
\text { Policy } \\
\{\text { Total frequency }\end{array}$ & $\begin{array}{c}\text { Disclosure on } \\
\text { explicit commitment } \\
\text { to Business Ethics } \\
\text { \{Total frequency\} }\end{array}$ & $\begin{array}{c}\text { Publishes Policy on } \\
\text { Whistle-blower } \\
\text { Protection } \\
\{\text { Total frequency }\} \\
\end{array}$ & $\begin{array}{c}\text { CSR/Sustainability } \\
\text { Committee } \\
\{\text { Total frequency }\}\end{array}$ \\
\hline Developed Countries & 1 & 0 & 1 & 1 & 1 & 0 \\
\hline Developing countries & 9 & 9 & 11 & 11 & 12 & 12 \\
\hline Emerging Countries & 8 & 9 & 11 & 11 & 11 & 11 \\
\hline G7 Countries & 0 & 0 & 1 & 1 & 1 & 0 \\
\hline Grand Total & 17 & 18 & 23 & 24 & 25 & 23 \\
\hline
\end{tabular}

Note **Above is a frequency table that provides a summary of the MNC's compliance to six international human rights regulations of CSR/sustainability and commitments to business ethics. We captured the figures using categorical variables 1 for compliance (Yes) otherwise 0 (No). We excluded the variable member of the ethical trading initiative from the above sample because none of the MNC's in our sample is a member of the UN ethical trading initiative.

Table 5: Descriptive Statistics of Global Human right score between 1990 - 2017

\begin{tabular}{|c|c|c|c|c|c|}
\hline Human rights violation & Domestic Economies & Parent/foreign economies & US and UK & US & UK \\
\hline Observations & 420 & 644 & 56 & 28 & 28 \\
\hline Mean & -0.918 & 0.853 & 0.965 & 0.599 & 1.331 \\
\hline Standard deviation & 1.336 & 1.560 & 0.656 & 0.564 & 0.530 \\
\hline Minimum Value & -3.237 & -2.425 & -0.173 & -0.173 & 0.757 \\
\hline Maximum value & 2.791 & 3.590 & 2.230 & 1.334 & 2.230 \\
\hline $1^{\text {st }}$ Percentile (bottom $1 \%$ ) & -3.146 & -2.210 & -0.173 & -0.173 & 0.757 \\
\hline 99 Percentile (top 99\%) & 2.553 & 3.440 & 2.230 & 1.334 & 2.230 \\
\hline Skewness & 0.664 & -0.492 & 0.193 & 0.193 & 0.839 \\
\hline Kurtosis & 3.066 & 2.077 & 2.545 & 1.363 & 1.990 \\
\hline
\end{tabular}

Note; **The human rights score indicates the degree to which government protect and respect human rights in a given country. The value ranges from around -3.8 to around 5.4 (the higher the better). Above figures represent global human rights score from 1990-2017 (source; Universal human rights index database, United nations Human rights commission). The domestic country represents the country where the human rights violations occur, Parent/foreign country represents the country of origin or the home country of the MNC's, US and UK represents combinations of human rights violations that occur in US and UK between 1990 - 2017 (US and UK constitutes about 54\% of our sample so we decided to further examine the figures), US represents human rights violations that occur in the US only between 1990-2017 and UK represents human rights violations that occur in the US only between 1990-2017. 